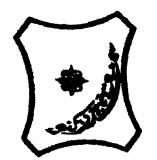

Bayero Journal of Pure and Applied Sciences, 12(2); 116 - 121

Received: October, 2019

Accepted: December, 2019

ISSN $2006-6996$

\title{
INTESTINAL PARASITES AMONG PRIMARY AND SECONDARY SCHOOL CHILDREN OF EGOR LOCAL GOVERNMENT AREA, EDO STATE
}

\author{
${ }^{1} *$ Omoruyi, Z. and ${ }^{2}$ Onimisi, Q.Z. \\ Department of Medical Laboratory Science, School of Basic Medical Sciences, University of Benin, \\ Benin City, Nigeria. \\ *Correspondence author: zainab.omoruyi@uniben.edu
}

\begin{abstract}
The study was carried out to determine the prevalence of gastrointestinal parasites among school children of Egor Local Government Area, Edo State. The correlation between their various activities like source of water, type of toilet, method of washing hands with the infection were examined. 250 stool samples of participants consisting of 111 males and 139 females were examined using the formol-ether concentration method. Questionnaires were administered to the children to collect information on Sociodemographic activities. The overall prevalence rate of the various parasitic infections was $16(6.4 \%)$, with $6(5.4 \%)$ prevalence rate of infection among males and $10(7.2 \%)$ among the females. From the study, the age group of 10-13 years old have high rate of infection $13(9.8 \%)$ followed by 6 -9years old $3(4.4 \%)$. Sex did not significantly affect the pattern of infection $(P>0.05)$ but age affected it significantly $(P<0.05)$. The children with Ascaris Iumbricoides recorded the highest prevalence rate of 6(2.4\%), followed by Hookworm (Ancylostoma duodenale) infection 3(1.2\%); Enterobius vermicularis 2(0.8\%); Entamoeba coli 2(0.8\%); Schistosoma japonicum 1(0.4\%); Strongyloides stercoralis $1(0.4 \%)$ and Round worm 1(0.4\%). The results further support public education on good personal hygiene and the dangers of open defeacation in fields and water ways.

Keywords: Children, Gastrointestinal, Helminth parasites, School, Socio-economic factors
\end{abstract}

INTRODUCTION

Intestinal parasitic infections are among the most common infections world-wide (Kang et al., 1998). Gastrointestinal infections impose a great and often silent burden of both morbidity and mortality rate on some populations in mostly developing countries (Saboya et al., 2013). Intestinal parasitic infection varies considerably from place to place in relation to the disease (Luka et al., 2000). Gastrointestinal infections are caused by helminths and protozoans which are mostly prevalent in developing countries, particularly in sub-Sahara, Africa (Hardhay et al., 2010). The public health importance of intestinal helminth infections continues due to their effects on both the nutritional and the immune status of infected Subsequently individuals, particularly those living in the tropical and subtropical areas (Hardhay et al., 2010)., Intestinal helminthic infections mainly affect the physical and mental development of children who are the most vulnerable. Overcrowding in most rural homes with infected persons and the change of environment from one locality acquiring the infection to a new area can lead to different routes of transmission. Transmission routes are more complex as some species are acquired through food or water contaminated with infective eggs or larvae, or are picked up directly via contaminated fingers while some have larvae that can actively penetrate through the skin, migrating eventually to the intestine and others are acquired by eating animals or animal products containing infective stages (Arora et al., 2011). Intestinal parasitic infections are amongst the most common infections worldwide (WHO, 2012). It is estimated that 3.5 billion people are infected with intestinal parasites of which 450 million are ill and the numbers of people infected is increasing in all WHO regions. Globally, it is estimated that all intestinal parasitic infections affect more than one third of the World's population with the highest rates of infection in school-age Children (Hotez, 2008). However, the objective of this study is to determine the prevalence of gastrointestinal parasites among school children of Egor Local Government Area, Edo State, Nigeria.

\section{MATERIALS AND METHODS \\ Study Area}

Egor is a city situated in Ovia North of Edo State, Nigeria. Egor geographical coordinates are $6023^{\prime} 0^{\prime \prime}$ North, $5034^{\prime} 0^{\prime \prime}$ East and the headquarter is in the town of Uselu. 
BAJOPAS Volume 12 Number 2, December, 2019

It has an area of $93 \mathrm{~km} 2$ and a population of 339,899 at the 2006 census. Egor Local Government Area is one of the eighteen local government areas in Benin City, Edo State. Benin City, the capital of Edo has an estimated population of 1,147,188 (National Population Commission, 2008) and lies between longitude $50^{\circ} 38^{\prime} 49.42^{\prime \prime} \mathrm{E}$ and latitude $6^{\circ} 20^{\prime} 95.09^{\prime \prime} \mathrm{N}$.

\section{Study Population}

Prior to the commencement of the research work, Ethical clearance was obtained from Ministry of Health Benin City, Edo State. The participants were informed on the causes of intestinal helminthiasis and the importance of living free from such infections. Informed consent was received from each participant. A total of 250 participants that consist of 111 males and 139 females were randomly selected for this study. Structured questionnaires were administered to the participants to obtain their demographic data.

\section{Sample collection and microscopic analysis} Stool samples were collected from 250 participants (130 Samples from Primary Schools, 60 samples each from Junior and Senior Secondary schools), in labelled universal containers and taken to the laboratory for analyses. The samples were analyzed using a previously described method by Cheesbrough, 2006. About $1 \mathrm{~g}$ of faecal sample was mixed in 4 $\mathrm{mL} 10 \%$ formal saline and sieved. To the filtrate, $3 \mathrm{~mL}$ of diethyl ether was added, mixed and spun at 3000rpm sediment was examined in both saline and iodine preparations using $x 10$ and $x 40$ objectives. Eggs were identified on the basis of their morphological features as described by (Soulsby,1982).

\section{Statistical Analysis}

Data obtained were analysed using Microsoft Excel for windows (2010 version) and SPSS version 17 as described by Ogbeibu (2005). Data was expressed in percentage when necessary and Chi-square statistics was to test the goodness of fit.

\section{RESULTS}

A total of 250 participants from Primary and Secondary schools in Egor, made up of 111 males and 139 females had their stool samples examined for the presence of gastrointestinal parasites. Of this number, $16(6.4 \%)$ participants were infected and more females $10(7.2 \%)$ than males 6(5.4\%) were infected (Table 1$)$. The highest prevalence occurred in participants aged $10-13$ years $13(9.8 \%)$ and $6-9$ years $3(4.4 \%)$, Table 2.

Ascaris lumbricoides has the highest prevalence 6(2.4\%); followed by Ancylostoma duodenale, $3(1.2 \%)$; Enterobius vermicularis, 2(0.8\%); Schistosoma mansoni, 1(0.4\%); Entamoeba histolytica, 2(0.8\%); Strongyloides stercoralis, $1(0.4 \%)$ and Round worm, $1(0.4 \%)$; Table 3.

There was statistically significant association between the Socio-economic factors and the infection $(P<0.05)$. Participants who used the bush as toilet had the highest rate of infection $7(2.8 \%)$ and those who used River water as their source of water had the highest prevalence of $9(3.6 \%)$. Also, the washing of hands after toilet use and the various method of washing hands were significantly $(P<0.05)$ associated with the prevalence (Table 4).

\begin{tabular}{|c|c|c|c|c|c|}
\hline SEX & No Examined & $\begin{array}{l}\text { No Infected } \\
(\%)\end{array}$ & OR & 95\% CI & P-Value \\
\hline MALE & 111 & $6(5.4)$ & 1.357 & $0.477-3.855$ & 0.566 \\
\hline FEMALE & 139 & $10(7.2)$ & & & \\
\hline TOTAL & 250 & $16(6.4)$ & & & \\
\hline
\end{tabular}

Table 2: Prevalence of intestinal parasites according to age group among the study subjects

\begin{tabular}{llll}
\hline $\begin{array}{l}\text { AGE-GROUP } \\
\text { (Yrs) }\end{array}$ & No Examined & No Infected (\%) & P-Value \\
\hline $6-9$ & 68 & $3(4.4)$ & 0.039 \\
$10-13$ & 132 & $13(9.8)$ & \\
$14-17$ & 50 & 0.00 & \\
TOTAL & 250 & $16(6.4)$ & \\
\hline
\end{tabular}


BAJOPAS Volume 12 Number 2, December, 2019

Table 3: Prevalence of gastrointestinal parasites among study subjects.

\begin{tabular}{ll}
\hline PARASITES & FREQUENCY (\%) \\
\hline Ascaris lumbricoides & $6(1.2)$ \\
Ancylostoma duodenale & $3(1.2)$ \\
Enterobius vermicularis & $2(0.8)$ \\
Schistosoma mansoni & $1(0.4)$ \\
Entamoeba histolytica & $2(0.8)$ \\
Strongyloides stecoralis & $1(0.4)$ \\
Round worm & $1(0.4)$ \\
TOTAL & $16(100)$ \\
\hline
\end{tabular}

Table 4: Prevalence of gastrointestinal parasites in schools according to their various activities

\begin{tabular}{|c|c|c|c|c|c|}
\hline Variable & $\begin{array}{l}\text { No. } \\
\text { examined }\end{array}$ & $\begin{array}{l}\text { No. infected } \\
(\%)\end{array}$ & OR & $95 \% \mathrm{CI}$ & P-Value \\
\hline \multicolumn{6}{|l|}{ Toilet Type } \\
\hline Water cistern & 164 & $3(1.2)$ & & & 0.000 \\
\hline Pit & 46 & $5(2.0)$ & & & \\
\hline Bucket & 12 & $1(0.4)$ & & & \\
\hline Nearby bush & 28 & $7(2.8)$ & & & \\
\hline \multicolumn{6}{|l|}{ Source of water } \\
\hline Bore hole & 150 & $2(0.8)$ & & & 0.000 \\
\hline Portable & 29 & $5(2.0)$ & & & \\
\hline River & 71 & $9(3.6)$ & & & \\
\hline \multicolumn{6}{|c|}{ Hand washing after toilet use } \\
\hline Yes & 195 & $2(0.8)$ & 32.951 & $7.211-150.577$ & 0.000 \\
\hline No & 55 & $14(5.6)$ & & & \\
\hline \multicolumn{6}{|c|}{ Method of Washing } \\
\hline Water only & 94 & $10(4.0)$ & & & 0.061 \\
\hline Detergent & 67 & $1(0.4)$ & & & \\
\hline Bar soap & 89 & $5(2.0)$ & & & \\
\hline
\end{tabular}

\section{DISCUSSION}

Many studies have been done on the prevalence of intestinal helminth infection all over the world including West Africa and Nigeria in particular. Gastro-intestinal parasites are identified as a cause of morbidity and mortality throughout the world particularly in the under developed countries (Odu et al., 2011a; Odu et al., 2013). The results from this study showed an overall prevalence of intestinal parasites $16(6.4 \%$ ) in Egor. This differed from the $50.4 \%$ reported by Adeyeba and Akinlabi (2002) in Oyo and Edogiawerie et al., (2016) that reported (18.7\%) in Edo State, but compare with $11.4 \%$ reported by Mordi and Okaka (2009) also in Edo state, Nigeria. The result is higher than $1.8 \%$ reported by Omudu et al., (2004); in Nigeria. The high prevalence recorded could be as a result of poor personal and environmental hygiene practices among the school children and in the study area. Prevalence in relation to sex showed that female participants $10(7.2 \%)$ had a relatively high prevalence rate than males $6(5.4 \%)$. This study agrees with findings by Brelet (2000), who reported higher prevalence of $(42.5 \%)$ in females than males (41.6\%). This was attributed to socio-cultural life style in this part of the State that involves females in more domestic activities that may expose them to contaminated water, food or disposing of waste; but contrary to the studies reported by (Ukpai et al., 2003) in Ikwuano, Abia State and (Ijagbone et al., 2006) in Borimope, Osun State, male having higher prevalence than female. There was no significant correlation in prevalence of gastrointestinal parasites with sex $(P=0.566)$. Previous studies by Ono et al. (2001) and Tohon et al. (2008) reported no significant difference in the prevalence of intestinal parasites in the two sexes. Awolaju and Morenikeji (2009) reported no significant among primary and post-primary schools children in Ilesa West, Osun State, Nigeria. These findings indicated that both sexes were equally exposed to enteric parasites. This Study showed that age specific prevalence rate was greater for age 10-13 years old (9.8\%), followed by $6-9$ years $(4.4 \%)$. However, the association is statistically significant $(P=0.039)$. The result agrees with (Houmsou et al., 2010), who reported that younger children below 14 years had high prevalence $(54.5 \%)$ of intestinal parasite than older ones carried out in Markudi, Benue State, Nigeria and (Reuben et al., 2013) reported age was significantly associated with the infection. This may be attributed to the fact that persons of the age group are often 
BAJOPAS Volume 12 Number 2, December, 2019

inquisitive, carefree and are more likely to get involved in activities involving contaminants. This study concurs with the findings of Adeyeba and Akinlabi (2002) and Mamadou et al., (2010), that the incidence is more in paediatric age groups and reaches highest in young adults, but may be related to the factors of poverty, poor personal hygiene and inadequate health services. Also it could be as a result of their low immunity, social and sanitary habits since they spend most of their time outdoors playing in areas where the sand may be contaminated with infected faecal sample or contaminated water.

The prevalence of each parasite encountered from the schools showed that infection with Ascaris lumbricoides recorded the highest prevalence $6(1.2 \%)$ followed by Ancylostoma duodenale $3(1.2 \%)$, Enterobius vermicularis $2(0.8 \%)$, Entamoeba histolytica $2(0.8 \%)$ while Schistosoma mansoni, Strongyloides starcoralis and Round worm had $1(0.4 \%)$ respectively. The high prevalence of Ascaris lumbricoides could be due to lack of proper sanitation and clean drinking water, poor standards of public and personal hygiene and inadequate health education promote the spread of such parasites. Some of the parasites have high fecundity rate which may last long in many places where sanitation and safe garbage disposal are nonexistence and the environment becomes thoroughly contaminated and infection is difficult to avoid (Crompton et al., 1993). While the prevalence of Ancylostoma duodenale is associated with open defaecation practices in fields mostly in this high agricultural community where humans' faeces are used as fertilizers and also where people go about bare footed (Crompton et al., 1993). This study was in line with similar studies in Nigeria by Luka et al., (2000) in Lere, Kaduna State, Damen et al., (2010) in Doi village, Plateau State and Egbuobi et al., (2013) in Akokwo Imo State. Enterobius vermicularis with $0.8 \%$ prevalence is in close relation to the $1 \%$ prevalence by Mordi et al., (2007) in Aniocha South, Delta State, Nigeria. The prevalence rate of Entamoeba histolytica $(0.8 \%)$ among the children is in accordance with the report of (Nematian et al., 2012) that Entamoeba histolytica is higher in children of school age in developing countries. Schistosoma mansoni and Strongyloides stercoralis (0.4\%) recorded the least prevalence and is in agreement with Mordi and Ngwodo (2007).

The risk factors examined such as sources of water supply was statistically associated with the prevalence of gastrointestinal infection in this study $(P<0.05)$. This might be because humans and domestic/wild animals use these sources of water for drinking that could lead to contamination with faeces and subsequent infection of exposed individuals. Also some wells in the towns are dug close to pit latrine and poor sanitation around the well enhances transmission. (Absar et al., 2010). Similarly, significant association was found among participants in relation to toilet types $(P<0.05)$. The participants that use nearby bush (open field defaecation) and pit latrines in their homes had higher prevalence $7(2.8 \%)$ and $5(2 \%)$ respectively, showed association between the disease and the toilet system. Similar observations were made among those that use open field defaecation toilet system by Uneke et al. (2006). This could be due to poor sanitation which might encourage flies and cockroaches to spread cysts and eggs of intestinal parasites (Absar et al., 2010). Erosion may wash away the faecal contaminant into the village water source, such as River in open field defaecation toilet system during rainy season. This practice could also enhance the transmission of cysts and eggs of parasites.

Those that indicated hand washing after using the toilet had high prevalence $14(5.6 \%)$. But there was no significant association (OR $=32.951,95 \% \mathrm{CL}=7.211-150.577 \mathrm{P}=0.000$ ) between the parasite and the infection. This outcome may be due to improper washing of hands (soaking of hands) especially when they are hungry or exposure to other risk factors. It has been reported that the hands readily become contaminated after defaecation even with the use of tissue paper. The human hands act as a common denominator in the transmission of intestinal parasites regardless of route of transmission (Absar et al., 2010). Hands can act as conduits to transfer parasites from surfaces in or outside the home, currency, food and animals (pets or wild).

\section{CONCLUSION}

The overall prevalence of these parasites in this study is a function of some risk factors of gastrointestinal parasites through unprotected water supply, improper sewage disposal and open defecation practices by the populace that lead to the exposure of faeces to scavenging animals and the drying effects of the sun and wind. In addition, it could be finger sucking and nail biting which had been found to encourage contamination by gastrointestinal parasites and transmission from one individual to another especially among children who live in closed communities, traditional houses, shared toilets and classrooms. 
BAJOPAS Volume 12 Number 2, December, 2019 RECOMMENDATIONS

To curb the extent of these practices, public education on the dangers of open defaecation practices in fields and waterways as well as behavioural modification and improved personal hygiene (such as nail trimming, hand washing before and after using of toilet, etc) should be integral part of control program for intestinal helminthiasis especially in school children. Also,

\section{REFERENCES}

Absar, A., Joseph, R.R. and Khalid, M.I. (2010). The global war against intestinal parasites-should we use a holistic approach? International Journal of infectious Diseases, (14): 732-738.

Adeyeba O.A and Akinlabi A.M (2002). Intestinal parasitic infections among school Children in a rural community, southwest Nigeria. Nig. $J$ parasito. 23:11-18.

Arora, D.R. and Arora, B.B. (2011).Medical Parasitology $3^{\text {rd }}$ Edition. CBS Publishers and Distributors PVT Limited, New Delhi, India. Pp 3-195.

Awolaju B.A and Morenikeji O.A (2009). Prevalence and intensity of intestinal parasites in five communities in southwest Nigeria. African Journal of Biotechnology. 8(18):4542-4546.

Brelet, C (2000). Women, Education and water in Africa. Technical document on Hydrology/UNESCO Paris. Pp 55-61

Crompton, D.W.T. and Savioli, L. (1993).Intestinal parasitic infections and urbanization.Bullet World Health Organisation, 71(1): 1-7.

Damen, J.G., Lar P., Mershak P., Mbaawujal, E.M and Nyary, B.W (2010). A Comparative study on the Prevalence of Intestinal Helminthes in Dewormed and Nondewormed students in a Rural Area of North-central Nigeria Lab. Med. 41(10): 585-589

Edogiawerie, D., Turay, A.A and Okpala, H.O (2016). Prevalance of Intestinal Helminths among Primary school children in Ihumududu community, Ekpoma, Edo state, Nigeria. Int. Journal of Community Research (IJCR). 5(1): $12-21$.

Egbuobi, R .C, Dike-Ndudim, J.N., Nwagbaraocha, M.A. and Nnodim, J.K. (2013).Intestinal parasitic infection among pupils in Umuezeaga autonomous community, Akokwa in Ideato North Local Government Area, Imo State, Nigeria. International improvement in the standard of education most especially in the aspect of conducive learning environment for children irrespective of their age group, proper waste disposal and water treatment before consumption should be advocated as a means of preventing exposure to these parasitic infections.

Research on Medical Sciences,1(1): $005-$ 009.

Hotez, P.J, Brindley, P.J, Bethony, J.M, King, C.H and Pearce, E.J et al. (2008). Helminth infections: the great neglected tropical diseases. $J$ Clin Invest. 118: 1311-1321

Houmsou, R. Amuta, E.Olusi, T. (2010).Prevalence of Intestinal parasites among primary school children in Markudi, Benue State, Nigeria. The Internet Journal Infectious Disease, 8(1):78-84.

Ijagbone, I. F. and Olagunju, T. F. (2006). Intestinal helminthes parasites in school children in Iragbiji, Boripe local government, Osun state, Nigeria. African Journal of Biomedical Research. (9): 6366.

Kang, G. May, M.S.,Jajan. D.P. Jasper, D.D. Minnie, M.M.,Marhta, V.I and Muliyil, J.P (1998)."Prevalence of intestinal parasites in southern rural India". Tropical Med and Intl Health.Vol 3:1, Pp 70-75.

Luka, S.A. Ajogi, I. and Umoh, J.U. (2000).Helminthosis among primary school children in Lere Local Government Area, Kaduna State, Nigeria. Nigerian Journal of Parasitology, (21): 109-116.

Mamadou, O., Nicaise, O., Guessar, N., Ahoua, $Y$ and Eieze, K (2010). Prevalence and Spatial distribution of Entamoeba histolytica / dispar and Giardia lamblia among school children in Agboville area (Cote d'ivoire), PLOS Negleted Tropical Diseases, 4(1):1-30.

Ministry of Land and Survey (2008). Edo State Ministry of Land and Survey Annual Report, pp 122.

Mordi, R.M. and Ngwodo, P.O.A. (2007). "A study of blood and gastro-intestinal parasites in Edo state," African Journal of Biotechnology. 19(6): 2201-2207.

Mordi RM and Okaka CE (2009). Prevalence of Intestinal parasites in Edo State. International Journal of Health Research. 2(3): 253-257. 
BAJOPAS Volume 12 Number 2, December, 2019

Nematian, J., Nematian, E., Gholamrezanezhad, A and Asgari, A.A (2012). Prevalence of Intestinal parasitic infections and their relationship with socio-economic factors and hygiene habits in Tehran Primary School students, Acta Tropica 92(3): 179-186

Odu, N.N., Okonko, I.O, and Erhi, O (2011a). Study of Neglected tropical diseases (NTDs): Gastro Intestinal Helminthes among school children in Port Harcourt, Rivers State, Nigeria.Report and Opinion. 3(9): 6-16.

Odu, N.N, Elechi, V.I and Okonko, I.O ( 2013). Prevalence of Intestinal Helminthes Infection among Primary School Children in Urban and Semi-Urban Areas in Port Harcourt, Rivers State, Nigeria. World Rural Observations, 5(1):52-61.

Omudu, E.A., Amuta, E.U and Feese, J.I (2004). The prevalence of intestinal helminths in children with different socio-economic background in Markurdi, Nigeria. $28^{\text {th }}$ annual conference Abstract (63) Niger. Soc. Parasitol 20: 71.

Ogbeibu, A.E. (2005). Practical approached to research and data handling. Mindex Publishing Co. Ltd., Benin City. Pp285.

Ono, K, Rai, S.K, Chikahira, et al. (2001). Seasonal distribution of enteropathogens detected from diarrheal stool and water samples collected in Kathmandu, Nepal. Southeast Asian J Trop Med Public Health. 32: 520-6.

Reuben, C.R. Katsa, M and Hassan, S.C. (2013). Prevalence of Intestinal Amoebasis in
School Age Children in Lafia, Nasarawa State, Nigeria. International Resource. Journal Biological Science, 2(7):42-45.

Saboya, M.I., Catala, L., Nicholls, R.S and Ault, S.K. (2013).Update on the mapping of prevalence and intensity of infection PLOS Neg/ for soil-transmitted helminth infections in Latin America and the Caribbean: a call for action. Trop Dis. 7(9): 2419.

Soulsby, E. J. L. (1982). Helminths, Arthropods and Protozoa of Domesticated Animals, $7^{\text {th }}$ Edition, Balliere, Tindall and Cassel, London. 809pp.

Tohon, Z.B., Mainassara, H.B., Garda, A., Mahamane, A.E., Bosqué-Olia, $\mathrm{E}$ and Ibrahim, M et al. (2008). Controlling Schistosomiasis: Significant Decrease of Anaemia prevalence one year after a single dose of praziquantel in Nigerian school children. Plos Negl Trop Dis. 2(5): e241

Ukpai, O.M. and Ugwu, C.O. (2003).The Prevalence of Gastro-intestinal Tract Parasite in Primary School Children in Ikwuano Local Government Area of Abia State Nigeria. Nigeria Journal Parasitology(240):129-136

Uneke, C. Eze, K. Oyibo, P.Alu, N. and Ali, E. (2006). Soil-transmitted helmith infection in school children in SouthEastern Nigeria. The Internet Journal of Third World Medicine, 4(1): 1-11

World Health Organization (2012). Slow sand filtration. Guidelines for drinking water quality.Hongkong $2^{\text {nd }}$ Edition.Vol. 3.Pg 105. 